\title{
OVARIECTOMY DURING GESTATION IN THE AMERICAN OPOSSUM, DIDELPHIS MARSUPIALIS VIRGINIANA
}

\author{
MARILYN B. RENFREE* \\ Zoology Department, University of Tennessee, Knoxville, Tennessee 37916, U.S.A.
}

\section{(Received 7th January 1974)}

Ovariectomy during gestation in mammals usually results in abortion or death of the embryos. In some mammals, however, the embryos survive and can develop for a short time.

In ferrets, implantation occurs when ovariectomy is performed on Day 10 post coitum (p.c.) but resorption follows immediately (Buchanan, 1969). In the guinea-pig, implantation occurs if ovariectomy is performed more than $48 \mathrm{hr}$ p.c. (Deanesly, 1960, 1966) but development continues normally only up to the 14th day. Ovariectomy of the nine-banded armadillo during delay results in precocious implantation (Buchanan, Enders \& Talmage, 1956) which occurs 18 to 20 days after operation (Enders, 1966); embryonic and fetal development proceed normally (Enders \& Buchanan, 1959). Marsupials, like armadillos, can dispense with their ovaries for the greater part of gestation. In the quokka, Setonix brachyurus, and the tammar, Macropus eugenii, the blastocysts remain in diapause if ovariectomy is performed before Day 2, some development takes place if the ovaries are removed between Days 2 and 7, but implantation and embryonic development proceed normally to term if ovariectomy is carried out after Day 7 (Tyndale-Biscoe, 1963, 1970). Parturition is inhibited and embryos are found dead in the uterus or lateral vaginal canals at term. Ablation of the corpus luteum after Day 7 in the brush possum, Trichosurus vulpecula, does not interfere with development to term: as in the quokka and tammar, parturition does not usually occur (Sharman \& Smith in TyndaleBiscoe, 1966). When the corpus luteum was removed at Day 11, however, two of four embryos were born.

These three monovular marsupials seemed to differ from the opossum, Didelphis marsupialis virginiana, in their response to ovariectomy. Hartman (1925) reported that double ovariectomy of this polyovular species invariably caused death of the embryos, but that laparotomy, hemi-hysterectomy or hemi-hysterectomy combined with unilateral ovariectomy either ipsilateral or contralateral to the uterus left in situ did not affect subsequent gestation. Buchanan (1969), re-examining Hartman's data, found that embryonic development had continued for several days when animals were ovariectomized at the blastocyst stage but, when performed later at Days 8 to 11, advanced or normal term fetuses were recovered from the uterus. Tyndale-Biscoe (1973)

* Present address: Institute of Animal Genetics, University of Edinburgh, West Mains Road, Edinburgh EH9 3JN. 
suggested that there is probably no real difference in the rôle of the corpus luteum between these two groups of marsupials. This paper presents results which support this idea.

Opossums were collected from around Knoxville, Tennessee, from January to July. They were accommodated outside in a large open cage $5 \mathrm{~m} \times 12 \mathrm{~m}$, divided into two sections. The animals were provided with individual nest boxes and housed in the ratio of four to five females to two males. These numbers fluctuated slightly due to recruitment to and removal from the colony. Females carrying pouch young were stimulated to resume oestrous activity by removal of the pouch young. Following removal of the pouch young, daily vaginal smears were prepared from Days 3 to 10 according to the method described by Pilton \& Sharman (1962). The usual time of return to oestrus and mating was between Days 5 and 7; the day of mating, as determined by the presence of spermatozoa in the smear, was designated Day 0 . Twelve opossums (of an average weight of $1700 \mathrm{~g}$ ) were anaesthetized with sodium pentobarbital (Nembutal $60 \mathrm{mg} / \mathrm{ml}$ ) given intravenously into the ear or tail vein at a dose rate of $50 \mathrm{mg} / \mathrm{kg}$. Ovaries and uteri were exposed by a mid-line incision through the anterior end of the pouch; both ovaries and the right uterus were removed. The diameters of blastocysts and vesicles, and the head lengths, crown-rump lengths or greatest lengths of the embryos were measured after recovery from the excised uterus. These were graded according to the thirty-five developmental stages for the opossum described by McCrady (1938). After operation, the animals were kept indoors until autopsy on Day 12, 1 day before the expected date of parturition, but one of the twelve animals was allowed to continue to Day 29, or 16 days beyond the expected parturition date. Representative embryos were fixed in formol saline for later histological examination.

The results for seven opossums are summarized in Table 1, which includes the data of Hartman (1925) for comparison. Of the remaining five opossums, the uteri of two (at Days 8 and 10 p.c.) contained only cloudy fluid at ovariectomy and no embryos were found, although there were new corpora lutea; the uterine glands had regressed. In two other opossums ovariectomized at Days 2 and 7, no embryos were found in the excised uterus, but corpora lutea were found in both ovaries and the uterus was normal, thus indicating failure to conceive. The remaining opossum, which had five 2-mm blastocysts (McCrady stage 16) at ovariectomy on Day 7 , had a flaccid collapsed uterus at autopsy as the uterine vasculature had been disrupted during surgery.

Ovariectomy after Day 2 of the 13-day gestation of the opossum does not cause immediate embryonic death and degeneration. Embryos at the sixteencell stage (McCrady stage 8) will grow to vesicles (stages 15 to 16 ) or even further to the cephalic-flexure stage (stage 26) while ovariectomy at the blastocyst stage allows development to continue to McCrady stages 26 to 29 . Ovariectomy between Days 6 and 8 gives some normal term fetuses (stage 35), but parturition is inhibited as shown by Hartman's animal at Day 15 and that which was killed on Day 29 in the present study; both had dead but fully developed term fetuses in the uterus. The present results confirm the data of Hartman, but his overall conclusion differed because he did not distinguish 
Table 1. Effect of ovariectomy of the American opossum during gestation

\begin{tabular}{|c|c|c|c|c|c|}
\hline $\begin{array}{l}\text { Day of } \\
\text { gestation }\end{array}$ & $\begin{array}{l}\text { Embryo condition } \\
\text { at ovariectomy }\end{array}$ & $\begin{array}{l}\text { McCrady } \\
\text { stage at } \\
\text { ovariectomy }\end{array}$ & $\begin{array}{l}\text { Day of } \\
\text { autopsy }\end{array}$ & $\begin{array}{l}\text { Embryo condition } \\
\text { at autopsy }\end{array}$ & $\begin{array}{l}\text { McCrady } \\
\text { stage at } \\
\text { autopsy }\end{array}$ \\
\hline $2^{*}$ & 8- to 16 -cell & 7 to 8 & 10 & Dead embryos with & $26 ?$ \\
\hline $2^{*}$ & 16 -cell & 8 & 10 & 1 degenerate embryo, & 26 to $27 ?$ \\
\hline $2^{*}$ & 16-cell & 8 & 10 & $\begin{array}{l}1 \times 1-\mathrm{mm} \text { vesicle, } 1 \times 2- \\
\mathrm{mm} \text { vesicle }\end{array}$ & $\begin{array}{l}15 \\
16\end{array}$ \\
\hline 3 & $11 \times 16$-cell & 8 & 12 & 3 degenerate embryos & 25 \\
\hline $4^{*}$ & Blastocysts & 10 & 10 & 1 normal, 1 dead, 4 & $?$ \\
\hline $4^{*}$ & Blastocysts & 10 & $9 \frac{1}{2}$ & 2 normal, 1 dead, & 26 to 27 \\
\hline $\begin{array}{l}5^{*} \\
5\end{array}$ & $\begin{array}{l}\text { Bilaminar blastocysts } \\
17 \text { blastocysts, } 0.6 \text { to } \\
0.72 \mathrm{~mm}\end{array}$ & $\begin{array}{l}14 \\
14\end{array}$ & $\begin{array}{r}8 \\
12\end{array}$ & $\begin{array}{l}\text { Normal } 8-\mathrm{mm} \text { vesicle } \\
2 \text { small vesicles } \\
5 \text { degenerate embryos }\end{array}$ & $\begin{array}{c}25 \\
23 \\
29 \text { to } 30\end{array}$ \\
\hline $\begin{array}{l}6^{*} \\
6\end{array}$ & $\begin{array}{l}\text { Endoderm formation } \\
15 \text { blastocysts, } 0.8 \text { to } \\
1.0 \mathrm{~mm}\end{array}$ & $\begin{array}{l}15 \\
15\end{array}$ & $\begin{array}{r}9 \\
12\end{array}$ & $\begin{array}{l}\text { Necrotic } \\
6 \text { degenerate embryos, } \\
4 \text { advanced, head fold }\end{array}$ & 29 to 30 \\
\hline 6 & $\begin{array}{l}14 \text { blastocysts, } 0.8 \text { to } \\
\text { to } 1.0 \mathrm{~mm}\end{array}$ & 15 & 12 & $\begin{array}{l}6 \text { degenerate embryos, } \\
\text { head fold } \\
2 \times 4 \text {-mm vesicles } \\
1 \text { full-term alive }\end{array}$ & $\begin{array}{l}29 \text { to } 30 \\
23 \\
35\end{array}$ \\
\hline 8 & $\begin{array}{l}12 \text { embryos, } 6 \text { somites, } \\
4 \text { to } 5 \mathrm{~mm}\end{array}$ & 23 to 24 & 12 & $\begin{array}{c}\text { Nothing remaining in } \\
\text { uterus - aborted? }\end{array}$ & 一 \\
\hline 8 & $\begin{array}{l}14 \text { vesicles, } 4 \text { to } 6 \\
\text { somites, } 5 \mathrm{~mm}\end{array}$ & 24 & 29 & $\begin{array}{l}7 \text { full-term embryos, } \\
\text { intact, dead }\end{array}$ & 35 \\
\hline $8^{*}$ & Head flexure stage & 26 & 13 & $\begin{array}{l}4 \text { haemorrhagic, term } \\
\text { embryos }\end{array}$ & 35 \\
\hline 10 & $\begin{array}{l}9 \text { live, (cervical flexure) } \\
4 \text { degenerate }\end{array}$ & 27 & 12 & $\begin{array}{l}7 \text { embryos, full term, } \\
\text { alive }\end{array}$ & 35 \\
\hline $11^{*}$ & \multirow{4}{*}{$\begin{array}{l}\text { Second lumbarflexure } \\
\text { fore limb paddle }\end{array}$} & 31 & 15 & \multirow{4}{*}{$\begin{array}{l}\text { Aborted? } \\
\text { Embryos: } 2 \text { normal, } \\
4 \text { abnormal? } \\
6 \text { normal, } 2 \text { dead } \\
\text { vesicles } \\
12 \text { normal fetuses }\end{array}$} & - \\
\hline $11^{*}$ & & 32 & 15 & & 35 \\
\hline $11^{*}$ & & 32 & 13 & & \\
\hline $11^{*}$ & & 32 & 13 & & $3 \dot{5}$ \\
\hline
\end{tabular}

between instances in which pregnancy terminated immediately after ovariectomy, a short time after ovariectomy, and those in which development proceeded but in which parturition failed.

The effects of ovariectomy in the opossum are indistinguishable from those in the quokka, the tammar and the brush possum, the only other marsupials so far studied. Tyndale-Biscoe (1970) suggests that the critical factor which allows development to continue in these species is the ability of the endometrium to remain in a secretory condition without further ovarian stimulation once it has been primed by secretions from the corpus luteum. In the brush possum, the 
luteal condition of the uterus is established by Days 6 to 7 and does not occur if the corpus luteum is removed before this time. The secretory phase declines at Day 15, and has ended by Day 17 when birth occurs (Pilton \& Sharman, 1962). In the opossum, the secretory phase of the uterus is established by Days 6 to 9 , begins to decline on Days 10 to 11 and is finished by Day 13 when birth occurs (Hartman, 1923). In the quokka and tammar, the luteal type of endometrium continues if the CL is removed after Days 7 to 8 , but declines by Days 25 to 27 around the end of gestation (Tyndale-Biscoe, 1963, 1970). In the latter species in intact, in ovariectomized or in anoestrous animals stimulated by progesterone, the luteal condition and the production of uterine secretion after Days 10 to 13 are apparently maintained by the developing embryo or its membranes (Renfree, 1972, 1973; Renfree \& Tyndale-Biscoe, 1973). It is possible that this is the explanation for the continuation of the luteal endometrium and the production of uterine secretion after ovariectomy in other species too, although both brush possum and opossum uteri contain far greater amounts of uterine secretion than do tammar or quokka uteri; the residual secretion after ovariectomy in the first two species may be sufficient to maintain embryonic development.

Although the corpus luteum can be dispensed with early in pregnancy, the marsupial ovary probably has other important functions because, in the three Australian and one American species examined, parturition is inhibited.

\section{REFERENCES}

Buchanan, G. D. (1969) Reproduction in the ferret (Mustela furo). II. Changes following ovariectomy during early pregnancy. F. Reprod. Fert. 18, 305.

Buchanan, G. D., Enders, A. G. \& Talmage, R. V. (1956) Implantation in armadillos ovariectomized during the period of delayed implantation. $\mathcal{F}$. Endocr. 14, 121.

Deanesly, R. (1960) Implantation and early pregnancy in ovariectomized guinea-pigs. F. Reprod. Fert. $1,242$.

Deanesly, R. (1966) The endocrinology of pregnancy and foetal life. In Marshall's Physiology of Reproduction, Vol. 3, p. 891. Ed. A. S. Parkes. Longmans Green, London.

ENDERs, A. C. (1966) The reproductive cycle of the nine-banded armadillo (Dasypus novemcinctus). Symp. zool. Soc. Lond. 15, 295.

Enders, A. G. \& Bughanan, G. D. (1959) Some effects of ovariectomy and injection of ovarian hormones in the armadillo. 7. Endocr. 19, 251.

Hartman, G. G. (1923) The oestrus cycle in the opossum. Am. F. Anat. 32, 353.

HaRtman, C. G. (1925) The interruption of pregnancy by ovariectomy in the aplacental opossum: a study in the physiology of implantation. Am. F. Physiol. 71, 436.

McCrady, E. (1938) The embryology of the opossum. Am. anat. Mem. 16, 1.

Pilton, P. E. \& Sharman, G. B. (1962) Reproduction in the marsupial Trichosurus vulpecula. F. Endocr. $25,119$.

Renfree, M. B. (1972) Influence of the embryo on the marsupial uterus. Nature, Lond. 240, 475.

Renfree, M. B. (1973) Proteins in the uterine secretions of the marsupial, Macropus eugenii. Devl Biol. 32,41 .

Renfree, M. B. \& Tyndale-Biscoe, C. H. (1973) Intra-uterine development after diapause in the marsupial, Macropus eugenii. Devl Biol. 32, 28.

Sharman, G. B. \& Smrth, R. F. G. (1966) Quoted in Tyndale-Biscoe, G. H. (1966) The marsupial birth canal, Symp. zool. Soc. Lond. 15, 233.

Tyndale-Biscoe, C. H. (1963) Effects of ovariectomy in the marsupial Setonix brachyurus. F. Reprod. Fert. $6,25$.

Tyndale-Biscoe, C. H. (1970) Resumption of development by quiescent blastocysts transferred to primed, ovariectomized recipients in the marsupial, Macropus eugenii. F. Reprod. Fert. 23, 25.

Tyndale-Biscoe, G. H. (1973) Life of Marsupials. Arnold, London. 